\title{
THE INFLUENCE OF CHIEF EXECUTIVE OFFICER INDIVIDUAL FACTORS ON CAPITAL STRUCTURE
}

\author{
Thomas Yulianto Prakoso \\ Business and Economic Faculty, University of Surabaya \\ Putu Anom Mahadwartha \\ Faculty of Business and Economics, Universitas Surabaya \\ anom@staff.ubaya.ac.id \\ Arif Herlambang \\ Faculty of Business and Economics, Universitas Surabaya \\ arif_herlambang@staff.ubaya.ac.id
}

\begin{abstract}
This study aims to analyze the effect of Chief Executive Officer (CEO) individual factor towards capital structure decision using Leverage as a dependend variable with Age (CEO Age), Tenure as independen variable amd Capex, ROA (Return on Asset), dan IO (Institutional Ownership) as control variable on LQ45 companies listed in Indonesia Stock Exchange (BEI) in the period 2012-2016. This research uses quantitative approach with single regression analysis model. This study uses sample of firms which are listed on LQ45 in IDX on 2012 2016. The number of final samples used in this study were 66 business entities with 330 observations. The study findings suggest that Age and ROA variables have negative and significant effect towards Leverage, while Tenure and IO variable have positive and significant effect towards Leverage. On the other hand, Capex variables does not indicate significant effect towards Leverage in LQ45 companies on the period 2012-2016.
\end{abstract}

Keywords: capital structure, age, tenure, leverage.

\begin{abstract}
Abstrak
Penelitian ini bertujuan untuk menganalisis faktor individu Chief Executive Officer (CEO) terhadap kinerja perusahaan yang menggunakan Leverage sebagai variabel dependen dengan Age (CEO Age), Tenure sebagai variabel independen serta Capex, ROA (Return on Asset), dan IO (Institutional Ownership) sebagai variabel kontrol pada perusahaan yang terdaftar LQ45 pada periode 2012-2016. Penelitian ini menggunakan pendekatan kuantitatif dengan model regresi linier. Sampel yang digunakan dalam penelitian ini adalah badan usaha yang termasuk dalam LQ45 Periode 2012 - 2016. Jumlah sampel akhir yang digunakan dalam penelitian ini adalah 68 badan usaha dengan 330 observasi.

Hasil penelitian menunjukkan bahwa variabel Age dan ROA berpengaruh signifikan negatif terhadap Leverage), hasil ini mendukung penelitian Custodio dan Metzger (2013), namun tidak sejalan dengan penelitian yang dilakukan oleh Chao et al. (2017). Sedangkan variabel Tenure berpengaruh positif signifikan terhadap Leverage, hasil ini mendukung penelitian Chao et al. (2017), namun tidak sejalan dengan penelitian yang dilakukan oleh Custodio dan metzger (2013). Variabel IO berpengaruh positif signifikan terhadap Leverage, hasil ini tidak sejalan dengan penelitian Mulyani et al. (2017). Di sisi lain, variabel Capex tidak menunjukan pengaruh signifikan terhadap Leverage pada perusahaan yang terdaftar dalam LQ45 periode 2012-2016. Hasil ini mendukung penelitian Dettamrong et al. (2015), namun tidak sejalan dengan penelitian yang dilakukan oleh Custodio dan Metzger (2013).
\end{abstract}


Kata Kunci: capital structure, age, tenure, leverage.

JEL: G32

\section{Research Background}

In this modern era, the world is growing fast and the trade traffic is also going fast, so the accurate decision making is needed to obtain the maximum benefits. The companies which have good corporate governance tend to have long term endurance in business. A company occasionally needs to take debt when it does not have enough funds to do certain action or to save tax. In taking the debt, many factors influence in making the decision. Decision making varies in each company. Each company certainly owned by certain party; whether by government, family or people. In Indonesia, 67\% companies which conduct listing are controlled by family (Claessens et al. 1999). Leverage has a relationship with various determinants from sides.

Leverage is very important in capital structure of a company. Many factors can influence the decision making of debt usage. Several studies (Fama and French 1989, CollinDufresne et al 2001, Custodio and Metzger 2014, Chao et al 2017, Mulyani et al 2016, Duffie and Singleton 2012) found that several factors of corporate governance have important roles in determining the level of leverage. Those factors are the age of CEO, the tenure of CEO, Capex, ROA and institutional ownership. From those available factors, there are several factors which have positive relationship on leverage; however, there are also factors which have negative relationship on leverage. Knowing the relationship between leverage and the factors that influence its movement is an important thing to learn so that in the future the company is able to regulate the right capital structure with various considerations of corporate governance factors.

Custodio and Metzger (2014) did research on the relationship between CEO characteristics and the financial policy of the company. They used samples of 25,562 CEOs in 1500 companies registered in Standard and Poor (S\&P). Custodio and Metzger (2014) found that CEO with more experience tends to have more debt, holding less cash and more involve in share repurchase. In this research, there are 4 dependent variables, and those are cash, leverage, dividend and repurchase. Independent variables used are CEO financial expert (the experience level of CEO financial), age (the age of CEO), sex (gender), tenure (the CEO period of working in the company), log asset (logarithm of company assets), asset volatility, capex (capital expenditure), R\&D (research and development), ROA (company revenue compared to total asset) and PPE.

Chao et al. (2017) did research on the influence of CEO power on capital structure of a company. Chao et al. (2017) used the company's data in China with the period of $2009-2013$. Chao et al. (2017) concluded that there is impact of CEO power on the company's debt, in which the impact is positive and significant on CEO with less power. Meanwhile, CEO with great power, they have insignificant negative impact on the company's capital structure. Dependent variable used is leverage, which is divided into market leverage and book leverage; meanwhile, the independent variables are power (the power of CEO), size (total asset of the company), growth, risk, profitability/ROA, tax, tenure, age and graduate (the origin of alma mater).

Detthamrong et al. (2017) did research to find out whether there is impact of corporate governance on the company's performance with non-financial companies in Thailand as samples in the period of 2001 - 2014. The conclusion of Detthamrong et al. (2017) is that there is no significant impact between corporate governance and leverage. The dependent variable used is leverage. Independent variables used are board size, board independence, board audit, board women, CEO duality, Ownership Concentration and also audit reputation. Meanwhile, the control variables used are industry return, firm size, firm age, capital expenditure, Current 
ratio, market to book ratio, cash flow to total asset ratio, fixed assets ratio and Return On Assets ratio.

Mulyani et al. (2016) did research about the impacts of family ownership in the company on leverage with the samples of all companies in Indonesia. Mulyani et al. (2016) found the negative impacts between family ownership and leverage. Dependent variable used is leverage, while independent variables used are size, ROA, payout, institutional ownership and cash.

From four researches by Custodio and Metzger (2014), Chao et al. (2017), Detthamrong et al. (2017), and Mulyani et al. (2016), independent total variable is 37 and it can be seen in table 1.1. Independent variables include CEO level of expertise (Financial expert CEO), Age, Sex, tenure, log asset, asset volatility, research and development, capex, return on asset (ROA). The selection criteria for the variables used are minimal exist in 2 studies and have a different significant level or 1 research with 2 different samples. Out of 37 variables that have been studied, the variables used as references are age, tenure, capex, ROA, and institutional ownership. Custodio and Metzger (2014) obtained the results of a study that showed that the CEO's lifespan had a negative impact on leverage. However, this is contrary to the research of Chao et al. (2017) which shows the insignificant positive effect of CEO age on leverage.

Custodio and Metzger (2014) shows that the period of tenure of CEO has significant negative impact on leverage. The longer the tenure of CEO in a company makes the tendency of capital structures that initially have more debt shifted into capital because of the saturation point of using debt. However, this is contrary to the research of Chao et al. (2017) which shows the significant positive impacts of CEO tenure on leverage. This is because the longer the company exist, the capital structure shifts from internal funds to external funds in accordance with the pecking order theory.

Custodio and Metzger (2014) also found the results of research which showed that capital expenditure had a significant negative impact on leverage. However, this is contrary to the research of Detthamrong et al. (2017) which shows that capital expenditure has a significant positive effect on leverage, where greater capital expenditure requires a large source of funds so that it requires more debt.

Custodio and Metzger (2014) together with Detthamrong et al. (2017) obtain the research results which indicate that Return on Assets has a significant negative impact on leverage. The greater the return obtained by the company, the usage of company funds will lead to retained earnings. However, this is contrary to the research of Chao et al. (2017) which shows a significant positive impact of ROA on leverage. The greater the ratio of income to assets, the more funds that can be used to pay interest on debt and the company wants the return to be obtained by itself. Meanwhile, Mulyani et al. (2016) obtained an insignificant negative result of ROA on leverage.

Mulyani et al. (2016) obtained the results of research that showed Institutional ownership had a positive impact on leverage of family companies. This is because the family wants the company's income to be consumed more personally. However, this is contrary to the sample of non-family companies which shows the significant negative impact of institutional ownership is on the movement of leverage.

This research was conducted in Indonesia with samples of companies listed in the LQ45 index. The usage of this index is due to the credibility of LQ45 to describe the whole public companies in Indonesia in order to find out the impact of good corporate governance on Leverage in Indonesia, so it would be able to provide an overview of the impact of good corporate governance on general leverage. The period is $2012-2016$.

\subsection{The impact of Age on Leverage}

Chaniago (2002) and Nursalam (2003) suggested that age is the length of life, which is from birth until present; and age determination uses year. 
Bertrand and Mullainathan (2003) explained that the older the CEO will be considered more senior and more respected, the thinking about risk that tends to be risk averse can affect the company's financial decision making. The same thing was said by Serfling (2012) who said that younger CEOs tend to be more aggressive and open up to opportunities for greater growth.

\subsection{The impact of Tenure on Leverage}

Tenure (tenur) has a lot of definitions, but in this context tenure is considered as the period of serving as CEO in a company. Tenure has a significant impact on decision making. Hambrick et al. (1993) explained that new CEOs have a focus on external direction, and tend to be more risk averse in financial decision making, so they are more likely to have less debt. According to Orens and Reheul (2013), CEOs with longer tenure will be more confident and will be more open to risk in financial decision making.

Chakraborty et al. (2007) said that CEOs with short tenures still have time to form longterm plans and take more risks. Meanwhile, CEOs with tenure approaching retirement time, they will tend to avoid risks and will use more internal funds.

\subsection{The impact of Capital Expenditure on Leverage}

According to Mulyadi (2005), capital expenditure is a cost that has benefits more than one accounting period (usually the accounting period is one calendar year).

Horngren et al. (2006) states "Capital Expenditure" is an expenditure that increases the capacity or efficiency of assets or that extends the useful life.

From some meanings above, it can be concluded that capital expenditures are all kinds of expenditures which have a useful period of more than one year in order to produce long-term benefits for the company.

Harris and Raviv (1991) said that the increasing leverage follows an increase in fixed assets, non-debt tax shields, growth opportunities, and company size. The statement from Harris and Raviv (1991) then continued more deeply with the research of Rajan and Zingales (1995), Sauve and Scheuer (1999), and Kremp and Stoss (2001). The existence of fixed assets used as collateral has a positive relationship with the issuance of debt, because it can reduce the risk of the borrower.

\subsection{The impact of Return on Asset on Leverage}

Return On Assets (ROA) is a ratio that shows the return on the amount of assets used in the company. Return On Assets (ROA) is a measure of management effectiveness in managing its investment. In addition, the return on investment shows the productivity of all company funds, both loan and own capital. The lower (smaller) the ratio, it would be in poorly condition, and vice versa. This means that this ratio is used to measure the effectiveness of the company's overall operations.

According to Kasmir (2008) Return On Assets (ROA) is a ratio that shows the return of the amount of assets used in the company.

I Made Sudana (2011) argued that "Return On Assets (ROA) shows the ability of a company by using all assets owned to generate profit after tax"

From the definition above, it can be concluded that Return On Assets (ROA) is a ratio that shows how much net income can be obtained from all the assets owned by the company. Therefore, the figures for profit after tax and the average wealth of the company are used. This ratio connects the profits obtained from the company's operations with the amount of investment or assets used to generate profits from the operation.

Amidu (2007) found an inverse relationship between short-term debt and company profitability. Abor (2005) found an inverse relationship between long-term debt and company profitability. Graham found an inverse relationship between total debt and company profitability. The conclusion they take is that companies with greater returns tend to have less 
debt.

Titman and Wassels (1988) suggest that a company with a high level of profit will use less debt. Rajau and Zingales (1995) also found an inverse relationship between profit and profitability of the company. Based on Fama and French (1998), the use of debt does not fully give benefits to tax. High leverage will make greater conflict between shareholders and lenders and this will affect the negative relationship between leverage and profitability.

\subsection{The impact of Tenure on Leverage}

Institutional ownership is the ownership of the number of company shares by a nonbank financial institution where the institution manages funds on behalf of other people. These institutions can be in the form of:

a. Mutual fund companies

b. Pension fund company

c. Insurance company

d. Investment company

e. Private foundations, endowments, or other large bodies that manage funds on behalf of

f. others

The higher the institutional ownership, the stronger the external control of the company and reducing agency costs, so the company will increasingly need to use lower dividends (Crulchley 1999).

Jensen and Meckling (1976) suggested that institutional ownership has an important role in minimizing agency conflict between management and shareholders. The existence of institutional investors is considered to have a monitoring mechanism for all decisions taken by management. This is because institutional investors are involved in strategic decision making. According to Tarjo (2008), institutional ownership is ownership of shares owned by institutions such as insurance companies, banks, investment companies, and others. Institutional ownership has a significant role in monitoring management because the existence of institutional ownership leads to more optimal control. Monitoring will guarantee the welfare of shareholders.

Institutional ownership represents a source of strength that will lead to increased optimal monitoring of company performance. This means that the better the percentage owned by institutional investors will make the efforts of monitoring more effective because it can control the habit of opportunity by managers. Monitoring activities will reduce agency costs because monitoring can make companies use lower debt (Isrina 2006). Based on Crutchley et al. (1999), institutional ownership has a positive impact on leverage. High leverage caused by company monitoring by credit providers makes managers to act in the same direction with the interests of lenders and shareholders, where these conditions can attract the entry of institutional ownership. Wahidahwati (2002) shows that the existence of institutional ownership has a significant influence on company leverage. This is consistent with the statement of Moh'd et al. (1998) where institutional investors in the manufacturing industry understand that their existence can effectively monitor the behavior of company managers. Jensen said that debt can be a substitute for institutional ownership of corporate governance, so the greater the institutional ownership of the company, the smaller the leverage. Based on the description above, it can be illustrated the research conceptual model shown in Figure 1. 


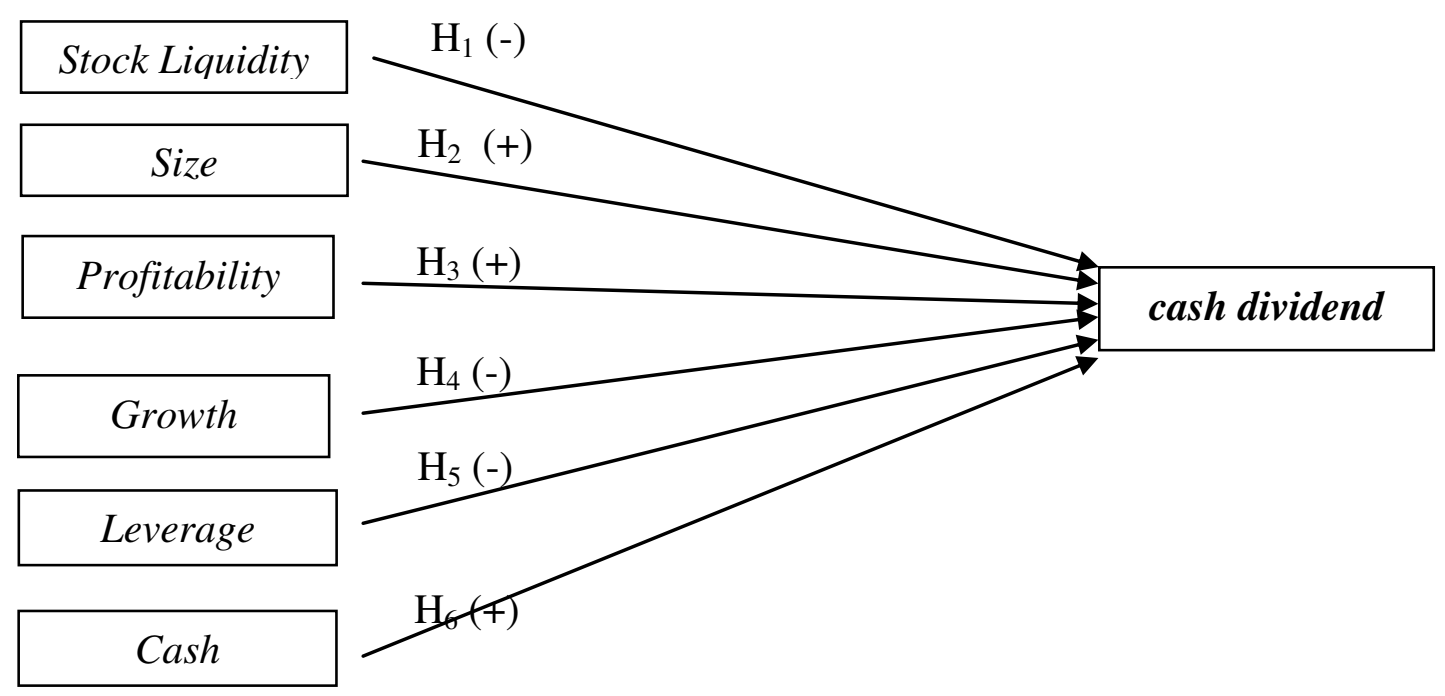

Figure 1. The impact of Independent variable and control on dependent variable

\section{Research Method}

The research carried out includes basic research, where this research was conducted to develop research that has been done before. Based on the stated objectives, this study can be classified into the type of causal research, because this research was conducted to test the independent variables (Age, tenure, capex, ROA, and institutional ownership) on the dependent variable (leverage) of companies included in LQ45 in the 2012 period -2016. Based on the approach, this research is included in the type of quantitative research because the research data used is taken from the secondary market and is used to prove the existing capital structure theory. Therefore, this study aims to determine the effect of age, tenure, capex, ROA, and institutional ownership on leverage.

The type of data used in this study is panel data, where the data used is quantitative data involving many samples in a certain time series. The population of this research is companies included in LQ45 on the Indonesia Stock Exchange for the period 2012-2016. Population targets are determined by criteria: (1) business entities listed on the Indonesia Stock Exchange for the period 2012-2016, (2) business entities have coherent financial reports and annual reports for the period 2012-2016, (3) business entities have financial statements per December 31 , (4) business entities have complete variable supporting data in the financial statements for the period 2012-2016.

This study uses a linear regression data processing method to determine the effect of independent variables on the dependent variable. The variables used in this study are dependent and independent variables. The dependent variable in this study is leverage, while the independent variables are Age, Tenure, Capex, ROA, and Institutional ownership. In this study there is 1 equation, namely:

$$
\text { Lev }_{i, t}=\alpha+\beta . \text { Age }_{\mathrm{i}, \mathrm{t}}+\beta . \text { Tenure }_{\mathrm{i}, \mathrm{t}}+\beta . \text { Capex }_{\mathrm{i}, \mathrm{t}}+\beta . \mathrm{ROA}_{\mathrm{i}, \mathrm{t}}+\beta . \text { Institutional ownership }_{\mathrm{i}, \mathrm{t}}+e
$$

Information :
Lev $_{i t}$
Age $_{i t}$
: leverage in company $\mathrm{i}$ with the period of $\mathrm{t}$
Tenure $_{i t}$
: age of $C E O$ in company $\mathrm{i}$ with the period of $\mathrm{t}$
: The tenure of CEO in company $i$ with the period of $t$ 


$\begin{array}{ll}\text { Capex }_{i t} & \text { : capital expenditure in company } \mathrm{i} \text { with the period of } \mathrm{t} \\ \text { ROA }_{i t} & \text { : Return on Asset of shares in company } \mathrm{i} \text { with the period of } \mathrm{t} \\ \text { Institutional ownership }_{i t} & : \text { institutional ownership in company } \mathrm{i} \text { with the period of } \mathrm{t} \\ \alpha & : \text { constant coefficients } \\ \beta & : \text { regression coefficient } \\ e & : \text { error }\end{array}$

\section{Result and Discussion}

\subsection{Descriptive statistics}

Descriptive statistics explain the description of the characteristics of each study sample that represents the population. The characteristics of the sample include the average value (mean), maximum value (max), minimum value (min) and the amount of data observed for each variable measured in each country and ASEAN.

Table 4.2 shows descriptive statistics that explain the characteristics of the object of this research. In descriptive statistics, it is known that the number of observations in this study is 330. There are several variables that have decimal units, namely capex, ROA, and IO. Tenure and age variables have units of years. The following is the result of the descriptive statistical data processing of LQ45 companies registered in Indonesia Stock Exchange for the period 2012-2016:

Table 1. Descriptive statistic of Company LQ45

\begin{tabular}{ccccccc}
\hline & LEVERAGE & AGE & TENURE & CAPEX & ROA & IO \\
\hline Mean & 0.5502 & 54.4211 & 5.7272 & 0.0830 & 0.0949 & 0.5583 \\
Median & 0.5441 & 54.0000 & 5.0000 & 0.0660 & 0.0686 & 0.5219 \\
Maximum & 1.6592 & 77.0000 & 24.0000 & 0.4841 & 0.8435 & 0.9924 \\
Minimum & 0.0852 & 37.0000 & 1.0000 & 0.0000 & -0.3841 & 0.0573 \\
Std. Dev. & 0.2179 & 6.8190 & 4.3778 & 0.0784 & 0.1368 & 0.2466 \\
Skewness & 0.4119 & 0.4116 & 1.2723 & 2.0833 & 1.8338 & 0.2105 \\
Kurtosis & 4.2810 & 3.1630 & 4.7527 & 8.9442 & 10.5920 & 1.9248 \\
& & & & & & \\
Jarque-Bera & 31.8966 & 9.6874 & 131.2830 & 724.5652 & 977.5644 & 18.3309 \\
Probability & 0.000000 & 0.007878 & 0.000000 & 0.000000 & 0.000000 & 0.000105 \\
& & & & & & \\
Sum & 181.5701 & 17959.00 & 1890.000 & 27.39781 & 31.33559 & 184.2705 \\
Sum Sq. Dev. & 15.62264 & 15298.45 & 6305.455 & 2.026542 & 6.165572 & 20.01974 \\
Observations & 330 & 330 & 330 & 330 & 330 & 330 \\
\hline
\end{tabular}

Source: Data processing from Eviews 8 program.

For the variable of Age, the $\max$ and $\min$ values are obtained from MAPI 2016 and MNCN 2016. For Tenure variables, the max and min values are obtained from AKRA 2016 and ANTM 2013 companies, ASRI 2012, BMRI 2013, and so on. For Capex variables, max and $\min$ values were obtained from MYRX 2012 and TRAM 2013,2015 companies and TAXI 2016. For ROA variables, $\max$ and $\min$ values were obtained from LPPF 2016 and ENRG 2016. For IO variables, the $\max$ and $\min$ values were obtained from the company ASII 2016 and MYRX 2013. 


\subsection{Regression results}

The following is the results of regression test

Table 2. Regression Test Result

\begin{tabular}{cccc}
\hline Variable & Coefficient & Std. Error & t-Statistic \\
\hline C & 0.7137 & 0.0532 & $13.3978^{*}$ \\
AGE & -0.0041 & 0.0007 & $-5.5479^{*}$ \\
TENURE & 0.0033 & 0.0009 & $3.4244^{*}$ \\
CAPEX & 0.0453 & 0.0686 & 0.6604 \\
ROA & -0.5451 & 0.0156 & $-34.7984^{*}$ \\
IO & 0.1598 & 0.0483 & $3.3075^{*}$ \\
R-squared & & 0.9835 & \\
Adjusted R-squared & & 0.9791 & \\
S.E. of regression & & 0.0789 & \\
F-statistic & & 220.6464 & \\
Prob(F-statistic) & & 0.0000 & \\
Durbin-Watson stat & & 1,7218 & \\
\hline
\end{tabular}

Notes: *: Significant on $1 \%, * *$ : Significant on $5 \%, * * *$ : Significant on $10 \%$

Source : Company financial statement LQ45, processed.

In this study, the dependent variable uses leverage and the independent variable uses Age, Tenure, Capex, ROA, and IO. In Table 3.2, the equation has a constant value of 0.7137. This means that when the independent variables in each regression model are worth 0 , the value of leverage will increase by 0.7137 .

Age variable has a coefficient of -0.0041 . This value explains that there is a negative influence between Age and leverage variables. If there is an increase or decrease in 1 unit of Age variable, then the leverage variable will move in opposite directions by 0.0041 assuming the other variables remain the same.

Tenure variable has a coefficient of 0.0033 . This value explains that there is a positive influence between Tenure and leverage variables. If there is an increase or decrease in 1 Tenure variable unit, then the leverage variable will move in the direction of 0.0033 assuming other variables remain the same.

The Capex variable has a coefficient of 0.0453 . This value explains that there is a positive influence between the Capex and leverage variable. If there is an increase or decrease in 1 unit of Capex variable, then the leverage variable will move in the direction of 0.1951 assuming other variables remain the same.

The $R O A$ variable has a coefficient of -0.5451 . This value explains that there is a negative influence between the variable of $R O A$ and leverage. If there is an increase or decrease in 1 unit of $R O A$ variable, then the leverage variable will move in the opposite direction by 0.5451 assuming other variables remain the same.

$I O$ variable has a coefficient of 0.1598 . This value explains that there is a positive influence between $I O$ and leverage variables. If there is an increase or decrease in 1 unit of $I O$ variable, then the leverage variable will move in the direction of 0.1598 assuming other variables remain the same.

\subsection{F test result}

The $\mathrm{F}$ test is conducted to determine whether the independent variables together have a significant effect on the dependent variable. The results of the F test can be seen from the 
probability of F-statistics. If the probability value of F-statistics gets smaller, then the influence of the independent variable on the dependent variable will be stronger.

In Table 3.2 it can be seen that the F-statistic probability is below $1 \%$, which is 0.0000 , so it can be concluded that the independent variables of Age, Tenure, and Capex control variables, ROA, and IO have a significant effect on the capital structure (measured with leverage) at the level of $1 \%$.

\section{4. $t$ test result}

t test is conducted to test the relationship of independent variables partially with the dependent variable.

\subsubsection{The impact of Age variable on leverage}

Age variable has a coefficient of -0.0041 and a significance level of 0.0000 . That is, the Age variable has a significant negative relationship to the leverage variable. These results support the Custodio and Metzger (2013) research, but are not in line with the research conducted by Chao et al. (2012) who found a significant positive relationship between Age and leverage.

Based on upper echelon theory, older CEOs have risk averse risk preferences so that they are less aggressive compared to younger age CEOs. There are several possibilities that can explain the conservative attitude of older CEOs. First, older executives may not have enough physical and mental strength to be able to understand new ideas and learn new things. Managerial age has been negatively associated with the ability to integrate information in decision making with confidence. Older executives will need more time to make decisions because older executives need more information to be able to accurately evaluate the decision. Second, older executives have a greater psychological commitment to the "status quo" of the organization (Hambrick 1993). Third, older executives may be at a point in life where financial security and career security are more important. Risky actions that may interfere will generally be avoided.

\subsubsection{The impact of Tenure variable on leverage}

Tenure variable has a coefficient of 0.0033 and a significance level of 0.0007 . It means that the Tenure variable has a significant positive relationship to the leverage variable. This result supports the research of Chao et al. (2017), but it is not in line with the research conducted by Custodio and Metzger (2013) who found a significant negative relationship between Tenure and leverage. This means that a type 1 error has occurred. Type 1 errors occur when the results of the research state that $\mathrm{H} 0$ is rejected, but actually $\mathrm{H} 0$ is correct.

Table 3. Type 1 error

\begin{tabular}{ccc}
\hline \multirow{2}{*}{ Decision } & \multicolumn{2}{c}{ Keadaan Sebenarnya } \\
& $\mathbf{H}_{\mathbf{0}}$ correct & $\mathbf{H}_{\mathbf{1}}$ correct \\
\hline \multirow{2}{*}{$\mathbf{H}_{\mathbf{0}}$ accepted } & Confidence level & Type II error \\
\multirow{2}{*}{$\mathbf{H}_{\mathbf{1}}$ accepted } & $1-\alpha$ & $\mathrm{B}$ \\
& Type 1 error & Power $/$ Test power \\
\hline
\end{tabular}

Source: Wikipedia.org

Hambrick et al. (1993) explained that new CEOs have a focus on external direction, and tend to be more risk averse in financial decision making, so they are more likely to have less 
debt. It can be concluded that the longer the CEO's tenure, the use of debt will be more so that leverage increases. Chakraborty et al. (2007) said that CEOs with short tenures still have time to form long-term plans and take more risks. Whereas for CEOs with tenure approaching retirement time, they will tend to avoid risks and will use more internal funds. Tenure has a significant positive effect on leverage, indicating that along with the increase in tenure, CEOs become more confident and will take on more challenges in corporate funding decisions.

\subsubsection{The impact of Capex on Leverage}

The Capex variable has a coefficient of 0.0453 and a significance level of 0.5096 . That is, the capex variable has an insignificant positive relationship to the leverage variable. These results support the study of Dettamrong et al. (2015), but not in line with the research conducted by Custodio and Metzger (2013) who found a significant negative relationship between capex and leverage. This means that type 1 errors have occurred.

Harris and Raviv (1991) said that increasing leverage follows an increase in fixed assets, non-debt tax shields, growth opportunities, and company size. The statement from Harris and Raviv (1991) then continued more deeply with the research of Rajan and Zingales (1995) and Sauve and Scheuer (1999), and Kremp and Stoss (2001). The existence of fixed assets used as collateral has a positive relationship with the issuance of debt, because it can reduce the risk of the borrower. But for leverage variables can still be influenced by various other factors. The proportion of capital expenditure that is very small compared to leverage causes no significant influence. Galizia and O'Brien (2001) also said that capital expenditure does not affect leverage because capital expenditure uses internal funds more often than loan funds.

\subsubsection{The impact of ROA variable on Leverage}

The variable of $R O A$ has a coefficient of -0.5451 and a significance level of 0.0000 . That is, the ROA variable has a significant negative relationship on leverage variable. These results support the research of Custodio and Metzger (2013) and Dettamrong et al. (2015), but not in line with the research conducted by Chao et al. (2017) and those who find a significant positive relationship between ROA and leverage. This result is also not in line with Mulyani et al. (2016), who found a negative significant relationship between ROA and leverage.

Titman and Wassels (1988) suggested that companies with high levels of profit will use less debt. Rajau and Zingales (1995) also found an inverse relationship between debt and company profitability. Based on Fama and French (1998), the use of debt does not fully provide tax benefits. High leverage will make a greater conflict between shareholders and lenders and this will have an impact with a negative relationship between leverage and profitability.

\subsubsection{The impact of $I O$ variable on Leverage}

$I O$ variable has a coefficient of 0.1598 and a significance level of 0.0011 . It means that $I O$ variables have a significant positive relationship on leverage variable. These results do not support the research of Mulyani et al. (2017) where there is a positive result of IO on leverage in family company samples and negative IO insignificance on leverage in non-family firms.

Based on Crutchley et al. (1999), institutional ownership has a positive impact on leverage. High leverage caused by company monitoring by credit providers makes managers to act in the same direction with the interests of lenders and shareholders, where these conditions can attract the entry of institutional ownership. Wahidahwati (2002) shows that the existence of institutional ownership has a significant influence on company leverage. This is consistent with the statement of Moh'd et al. (1998) where institutional investors in the manufacturing industry understand that their existence can effectively monitor the behavior of company managers. Mehran (1992) explains that the higher institutional ownership, the higher the use of debt. This 
happens because a large control from the institutional side causes the manager to be able to invest better, thus requiring additional funds through debt for funding.

The coefficient of determination used is adjusted-R2, where in model 1 has a value of 0.9835 with leverage as the dependent variable. This means that changes in leverage variables can be explained well by independent variables (Age and Tenure) and control variables (Capex, ROA, and IO) of $98 \%$, while the remaining $2 \%$ is explained by other variables not included in this study.

\section{Conclusion}

Based on the results of hypothesis test using the F test with software Eviews 8, it was found that the results of statistical calculations showed $\mathrm{F}$ count $=220.6464$ with a probability of $0.0000<0.05$. This means that together the independent variables (Age, Tenure) and control variables (Capex, ROA, IO) have a significant influence on leverage.

Based on the results of the hypothesis test by carrying out the $t$ test, the result has been obtained is that age variable, and ROA have a significant negative effect on leverage, and the tenure and IO variables have a significant positive effect on leverage variable. The capex variable has a significant positive effect on leverage.

Age variable has a significant negative effect on leverage. This is because the older the age of the CEO, the executive tends to be more risk-averse. Executives also tend to take longer to accept new ideas. Investors with risk seeking risk preferences are certainly better off choosing CEOs at a young age because they are more courageous in taking risks in corporate funding. Companies can consider when they will appoint a new CEO whether the company needs more funding on debt or internal funds.

Tenure variables have a significant positive effect on leverage. The longer they have served as CEOs, the more confident they will be and will take on more challenges in corporate funding decisions. Investors who have risk-seeking risk preferences are better off looking for long-term CEOs because they tend to be more courageous in making debt use decisions. Companies can consider when they will appoint a new CEO whether the company needs more funding on debt or internal funds.

The capex variable has a significant positive effect on leverage. This is because capital expenditures made by companies tend to have small proportions so that they do not have a significant influence on the decision making of corporate debt usage. Capital expenditure also tends to use internal funds rather than using debt.

The ROA variable has a significant negative effect on leverage. This is because the greater the Return on Asset of the company, the greater the profit that can be used as Retained Earnings. So that the use of funds through retained earnings will be greater and reduce the proportion of debt use as a source of corporate funding. Investors with risk-seeking risk preferences are better considering increasing company profits with the company's debt level. Meanwhile, the company should be able to calculate the level of debt that can provide benefits for the company through increasing company profits.

$I O$ variables have a significant positive effect on long-term debt. This is because the existence of institutional ownership requires monitoring extra management performance that can be done by creditors. For investors with risk seeking risk preferences it is better to follow a company with a high level of institutional ownership because it has a better monitoring level. For companies this can be taken into consideration in determining the right funding for the company.

\section{References}

Chao C, Chur. 2017. The Impact of CEO Power on Corporate Capital Structure: New Evidence from Dynamic Panel Threshold Analysis. International Review of Economics and Finance 51: 107-120. 
Custodio C, Metzger D. 2013. Financial Expert CEOs: CEO's Work Experience and Firm's Financial Policies. Journal of Financial Economics 114:121-158.

Detthamrong U. 2017. Corporate Governance, Capital Structure and Firm Performance: Evidence from Thailand. Research in International Bussiness and Finance 42: 689709.

Moh'd MA. 1998. The Impact of Ownership Structure on Corporate Debt Policiy: A Time Series Cross-Sectional Analysis. Finance Review 3: 85-99.

Mulyani E et al. 2016. Dividens, Leverage, and Family Ownership in the Emerging Indonesian Market. Journal of International Financial Markets, Institutions \& Money 43: 16-29. 